\title{
SERBIAN STUDIES
}

JOURNAL OF THE NORTH AMERICAN SOCIETY FOR SERBIAN STUDIES

Vol. 31

2020

No. $1-2$

EDITOR

Slobodanka Vladiv-Glover, Monash University, Australia

ASSOCIATE EDITORS

Milica Bakić-Hayden, University of Pittsburgh

Jelena Bogdanović, Iowa State University

Tomislav Longinović, University of Wisconsin, Madison

EDITORIAL BOARD

Jadranka Bozić, National Library of Serbia

Dubravka Đurić, Singidunum University, Belgrade

Lilien Filipovitch-Robinson, George Washington University

Aleksdandar Jerkov, University Library "Svetozar Marković," Belgrade

Radmila Gorup, Columbia University

Dijana Mitrović Longinović, University of Wisconsin, Madison

Biljana D. Obradović, Xavier University of Louisiana

Nada Petković, University of Chicago

Igor Perišić, Institute for Literature and Arts, Belgrade

Ljubica Popovich, Vanderbilt University

Ida Sinkević, Lafayette College

Svetlana Tomić, Alpha University, Belgrade

Marko D. Petrović, Geographical Institute, Serbian Academy of Sciences and Arts Milan Vukomanović, University of Belgrade 